ISSN 1991- 8690

Website: http://jsci.utq.edu.iq

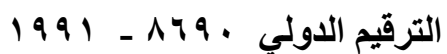

Email:utjsci@utq.edu.iq

\title{
Impact of Al-Najebiya thermal energy power plant on aquatic ecosystem of
} Garmat Ali canal.

\section{Monthly differences in nutrient budget and TDS}

Sadek A. Hussein; I. J. Al-Shawi* and A. M. Abdullah

Department of Fisheries and Marine Resources; College of Agriculture \&

Marine Science Centre*, University of Basrah, Iraq.

\section{Summary}

Monthly variations in concentrations of nutrients (nitrite, nitrate, phosphate and silicates) along with total dissolved solids (TDS) were investigated in Al-Najebiya electricity power generating station (N.S).The study extended from November 1997 to October 1998. Three sites were selected for sampling, based on intake and discharge points. The lowest nitrite value $(0.15 \mu \mathrm{g}$ at. N/L) was encountered in November and the highest $(1.37 \mu \mathrm{g}$ at. $\mathrm{N} / \mathrm{L})$ in January. Nitrate $\left(\mathrm{NO}_{3}\right)$ revealed considerable rise in concentrations near effluent, as well, and the highest (34.95 $\mu \mathrm{g}$ at. N/L) was in August. Maximum value of phosphate $(4.75 \mu \mathrm{g}$ at. P/L) was encountered near the effluent discharging point. Silicate $\left(\mathrm{SiO}_{3}\right)$ concentration was also distinctly high in this site, the maximum value $(201.1 \mu \mathrm{g}$ at. $\mathrm{Si} / \mathrm{L})$ recorded in August. TDS exhibited higher concentrations in sites closer to thermal discharge as well (1675mg/L). No previous ecological, long or short term, work of the type was recorded for the investigated site or any other similar locations in the country. 


\section{Introduction}

Care imposed on inland natural waters and on water quality criteria plays substantial roles in sustainable development of societies. Also resources of natural waters had got to bear impact of various pollutants due to unwise use or discharges of agricultural, industrial and man made pollutants (Odum, 1971; Hussein, 2001). Nitrogen and phosphorus are considered the more vital elements regulating and limiting growth and their compounds are of substantial importance in composition of various body components (Lee, et al. 1995). It is obvious that levels of nitrogenous compounds are high in polluted environments. This may associated with decline in concentration of dissolved oxygen (Lind, 1979), whereas phosphorus is added from various man and domestic activities including sewage and organic pollution in particular fertilizers and detergents (Hussein, 2001). Nutrients budget in some Iraqi waters were previously studied by many workers including (Al-Nimma, 1982; Hassan, 1997; Maulood et al., 1994; Al-Lami, et al. 1998; Al-Rubae, 1997; Al-Saadi et al., 1996; Fahad, 2002 and Hussein and Fahad, 2008), but no previous work of the type was executed, on any inland water body, to work out the impact of thermal discharges of industrial plants on nutrient budget. It is therefore, the present work is aiming at providing clear picture on the status of these parameters including TDS values, In Al-Najebiya electricity generating power station (N.S).

\section{Study area}

N.S was established in 1959 on bank of Garmat Ali canal (G. C) that possesses an important link with the Shatt Al-Arab River. The station consists of two generating units to produce electricity $(200 \mathrm{~mW} / \mathrm{h})$. It requires $34000 \mathrm{~m}^{3} / \mathrm{h}$ of raw water for cooling purposes. Three sites were selected in G.C to execute the work. The former location designated by the symbol $\mathrm{N} 1$ is situated near intake point westward N.S, the second site N2 lie closer to initial discharging point of heated effluents at direction eastward N.S and about $500 \mathrm{~m}$ apart from intake and, the latter site designated by N3 is located $500 \mathrm{~m}$ apart from N2. However, detailed descriptions to the study area, sampling locations and mechanism of power generating processes are provided in Hussein et al. (2001).

\section{Materials and Methods}

Water samples were collected on monthly basis from the selected locations. Benderschneiden and Robinson (1952) method clearly described by Parsons et al. (1984) was used to determine Nitrite $\left(\mathrm{NO}_{2}-\mathrm{N}\right)$ level. Happy-Wood and Priddle (1984) method clarified by Person et al. (1984) was adapted to measure nitrate $\left(\mathrm{NO}_{3}-\mathrm{N}\right)$ concentrations. Phosphate $\left(\mathrm{PO}_{4}^{-}\right)$was determined by consulting Murphy and Riley (1962) method. Silicate levels were measured according to Mullin and Riley (1955) methods described by Parson et al. (1984). TDS values were measured by consulting APHA (1985). Statistical analyses by consulting completely randomized design (C.R.D) was used to analyze the results and calculating the significant differences among means depending on R.L.S.D. Minitab packed statistical program was used for the analyses of the data. 


\section{Results}

Table (1) reveals values of correlation coefficient between water temperature and four studied parameters. It is clear that water temperature is highly correlated with silicate and TDS, whereas $\mathrm{NO}^{-}$exhibited stronger correlation than phosphate except in site $\mathrm{N} 3$. Figure (1) shows monthly and localized variations of nitrite values. It is obvious that $\mathrm{NO}_{2}$ calculated values were lower than nitrate throughout the study period. The highest $(1.37 \mu \mathrm{g}$ at. $\mathrm{N} / \mathrm{L})$ recorded in January at site $\mathrm{N} 2$ and the lowest $(0.15 \mu \mathrm{g}$ at. N/L) encountered in November at the same site. Statistical analysis indicates insignificant differences ( $\mathrm{P}>0.05)$, among the three selected sites.

Fig. 2 reveals monthly and localized changes in nitrate $\left(\mathrm{NO}_{3}-\mathrm{N}\right)$ concentrations. It is clear that values are high at both sites of discharging thermal effluents and were ranging from 7.05-26.74, 16.16-34.95 and 7.83-27.0 $\mu \mathrm{g}$ at. $\mathrm{N} / \mathrm{L}$ in $\mathrm{N} 1, \mathrm{~N} 2$ and $\mathrm{N} 3$ sites. Statistical analysis reveals significant differences $(\mathrm{P}<0.01)$ among sites $(\mathrm{F}=28, \mathrm{n}=1,36)$.

Figure (3) shows monthly and station wise variations in phosphorous concentrations. The highest value $(4.75 \mu \mathrm{g}$ at. $\mathrm{P} / \mathrm{L})$ encountered in May at $\mathrm{N} 2$ and the lowest $(0.28 \mu \mathrm{g}$ at. $\mathrm{P} / \mathrm{L})$ in January from N2. Statistical analysis indicate significant differences $(\mathrm{P}<0.01)$ among sites $(\mathrm{F}=15, \mathrm{n}=1,36)$.

Figure (4) illustrates monthly and localized changes of silicate. Maximum values (169.9, 201.2 and $172.5 \mu \mathrm{g}$ at. Si/L) were recorded from sites N1, N2 and N3 respectively during August and the minimum $(24.0,24.9$ and $22.0 \mu \mathrm{g}$ at. $\mathrm{Si} / \mathrm{L})$ were measured in December from the above sites in the same ordered. Statistical analysis shows significant differences $(\mathrm{P}<0.01)$ among the three sites $(\mathrm{F}=13.1, \mathrm{n}=1,36)$.

Monthly changes in values of TDS in the three selected sites are indicated in Figure 5. Levels were ranging between 905-1666, 1024-1675, and 960- $1671 \mathrm{mg} / \mathrm{L}$ in the sites N1, $\mathrm{N} 2$ and N3 respectively. It is obvious that sites of thermal effluents reflect the highest concentrations. The highest values, in all sites, were encountered in September and the lowest in January. Significant variations $(\mathrm{P}<0.01)$ in $\mathrm{TDS}$ were detected among investigated sites $(\mathrm{F}=3, \mathrm{n}=1,36)$.

\section{Discussion}

The study reveals that values of unstable nitrite $\left(\mathrm{NO}_{2}^{-}\right)$were always lower than nitrate $\left(\mathrm{NO}_{3}^{-}\right)$. The latter represent the dominant form of nitrogen compounds and rarely exceed $10 \mathrm{mg} / \mathrm{L}$ (Lind, 1979) the highest values of $\mathrm{NO}_{2}^{-}$, however, were recorded from sites of thermal discharge. This is in agreement with Hillbricht and Simn (1988) who studied impact of thermal effluents in Poland. Increase in nitrite levels at sites affected by thermal effluents may be attributed to continuous activity of microorganism's that stimulated by elevated temperature (Payne, 1986). Rise in water temperature also reduce solubility of oxygen, accelerate oxidizing organic matters and release nutrients to the system (Hussein,2001) and stimulate nitrification (Shrimali and Singh, 2001). High levels of oxygen content assist in reducing $\mathrm{NH}_{3}$ level and recruit $\mathrm{NO}_{3}$ due to activity of decomposers (Ruttner, 1963). Significant correlation $(\mathrm{P}<0.05)$ was detected between water temperature and nitrate (Table 1).

Phosphate was also high in outlet point. This also explained by the rise in ambient water temperature and current flow (Reid, 1961; Holtan et al, 1988; Hillbricht and Simn, 1988). Hussein (2001) speculated on causes of phosphate sources in rivers and found that 
values depend on several factors including urban population density who releasing detergent, land cultivation activities, type of soil and geological composition of substrate. Phosphate values were found to be correlated with temperature (Table 1). Abnormal abundance of phosphate exceeding the capacity of the water body normally leads to eutrophication (Sharpley, 2001).

Values of silicate were found to be high closer to effluent discharge in summer months. This coincide with Hillbricht and Simn (1988) finding in Poland. High water temperature serves in releasing insoluble $\mathrm{SiO}_{3}$ to soluble state (Reid, 1961). Decomposition of diatoms, which associate with elevated temperatures, also adds substantial proportion of silicate to the environment (Klarer and Hikman, 1975; Happy-Wood and Priddle, 1984). Results indicate that silicate positively correlate with water temperature.

Notable rise in TDS values were detected in sites of effluent discharge. Also, the highest concentrations, in general, were encountered during warmer seasons and associated with decline in water level and rise in salinity, nutrients and evaporation serve in increasing TDS (Hammer, 1979). Positive correlation was found between water temperature and TDS values.

Table (1). Values of Correlation coefficient between water temperature and some Physico-chemical conditions at the three stations.

\begin{tabular}{|c|c|c|c|}
\hline Factors & N1 & N2 & N3 \\
\hline Water Temp. $\times$ Salinity & 0.82 & 0.82 & 0.79 \\
\hline Water Temp.×Turbidity & -0.68 & -0.38 & -0.58 \\
\hline Water Temp.×D.O & -0.96 & -0.85 & -0.82 \\
\hline Water Temp.×BOD & 0.68 & 0.64 & -0.22 \\
\hline Water Temp. $\times T$. Hardness & 0.63 & 0.56 & 0.68 \\
\hline Water Temp. $\times \mathrm{Ca}+^{2}$ & 0.65 & 0.80 & 0.61 \\
\hline Water Temp. $\times \mathrm{NO}_{3}$ & 0.67 & 0.71 & 0.53 \\
\hline Water Temp. $\times \mathrm{PO}_{4}$ & 0.57 & 0.55 & 0.60 \\
\hline Water Temp. $\times \mathrm{SiO}_{3}$ & 0.89 & 0.89 & 0.96 \\
\hline Water Temp.xTDS & 0.78 & 0.86 & 0.76 \\
\hline
\end{tabular}




\section{J.Thi-Qar Sci Vol.1 (4)}

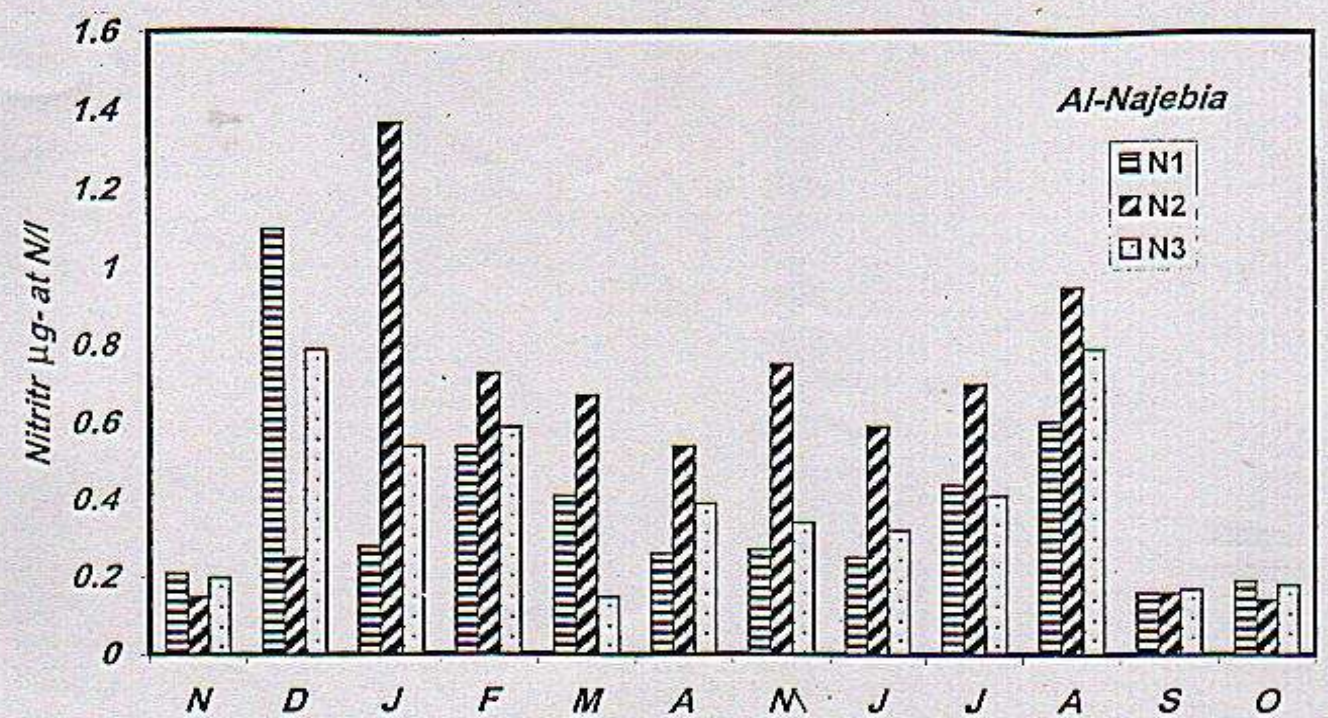

Figure(1) Monthly and localized variations in nitrite concentration

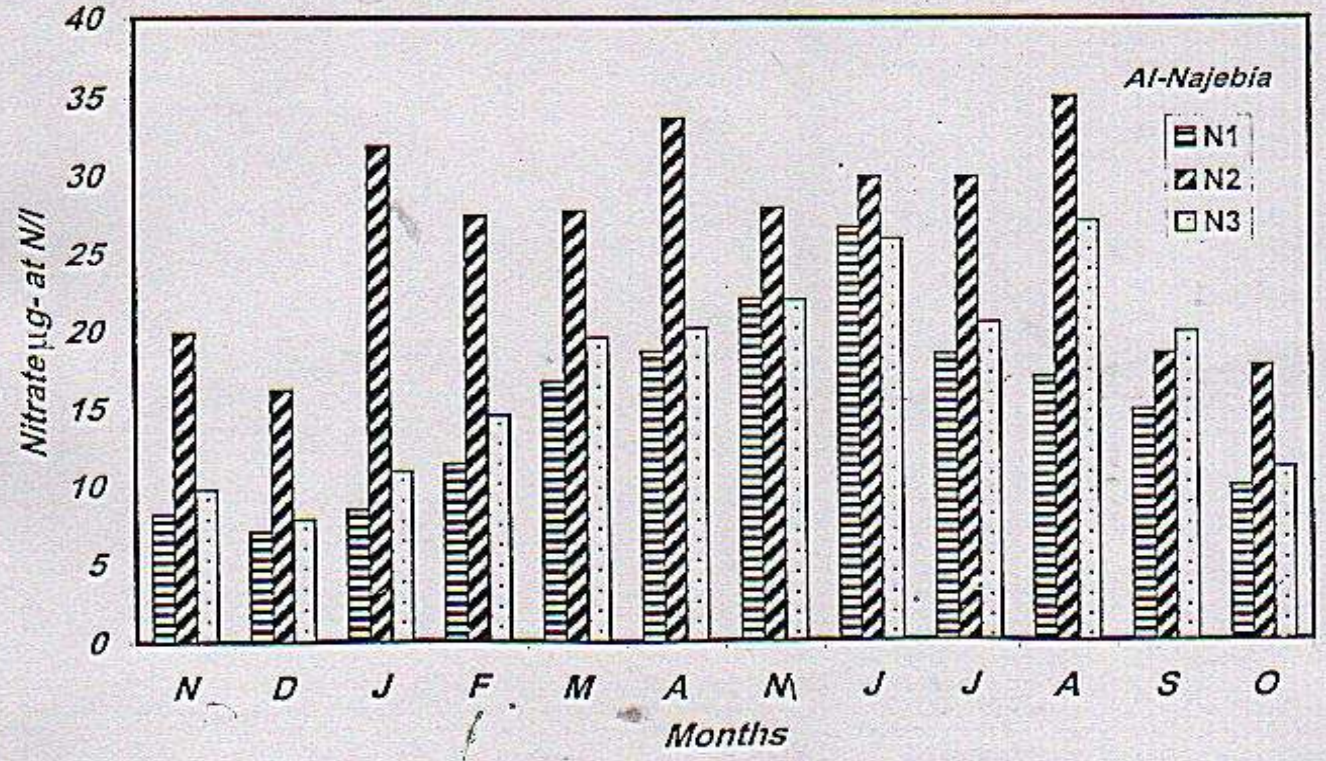

Firgure(2) Monthly and localized variations in nitrate concentration 


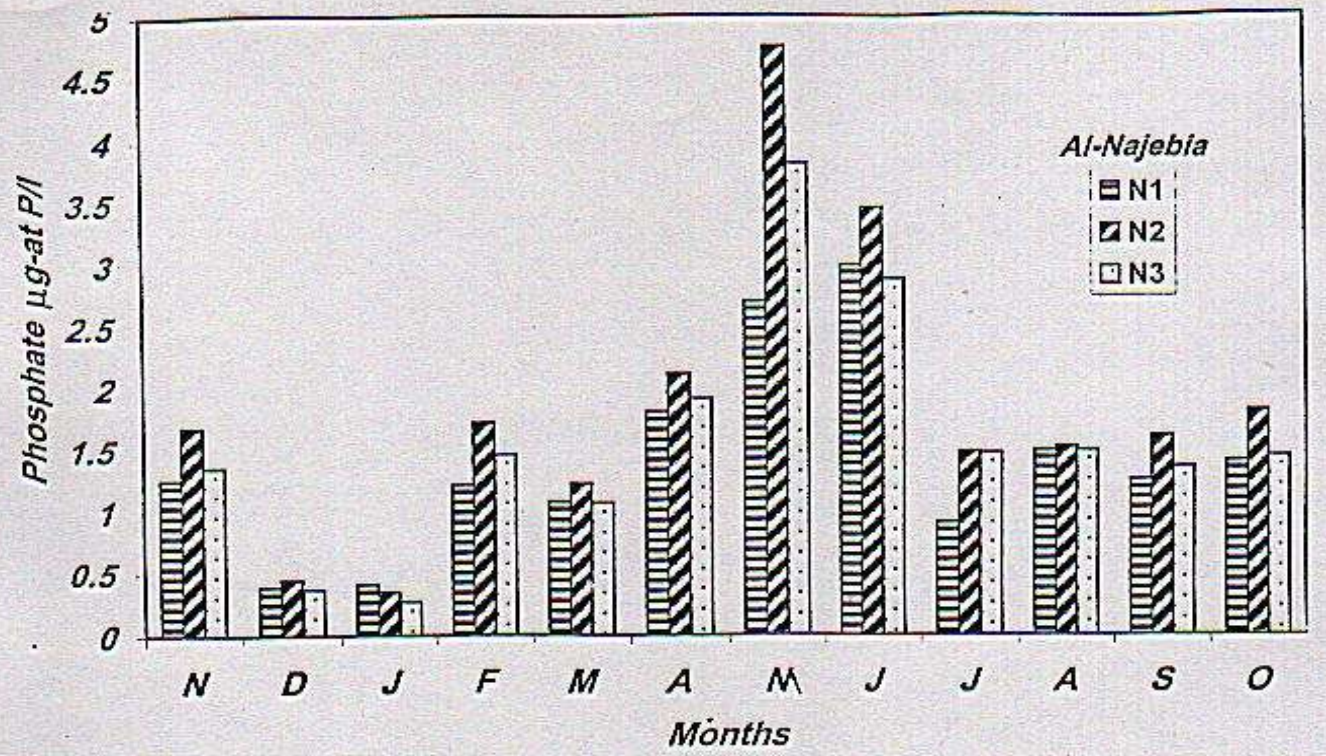

Fisure\{ 3$\}$ Monthly and localized variations in phosphate concentration

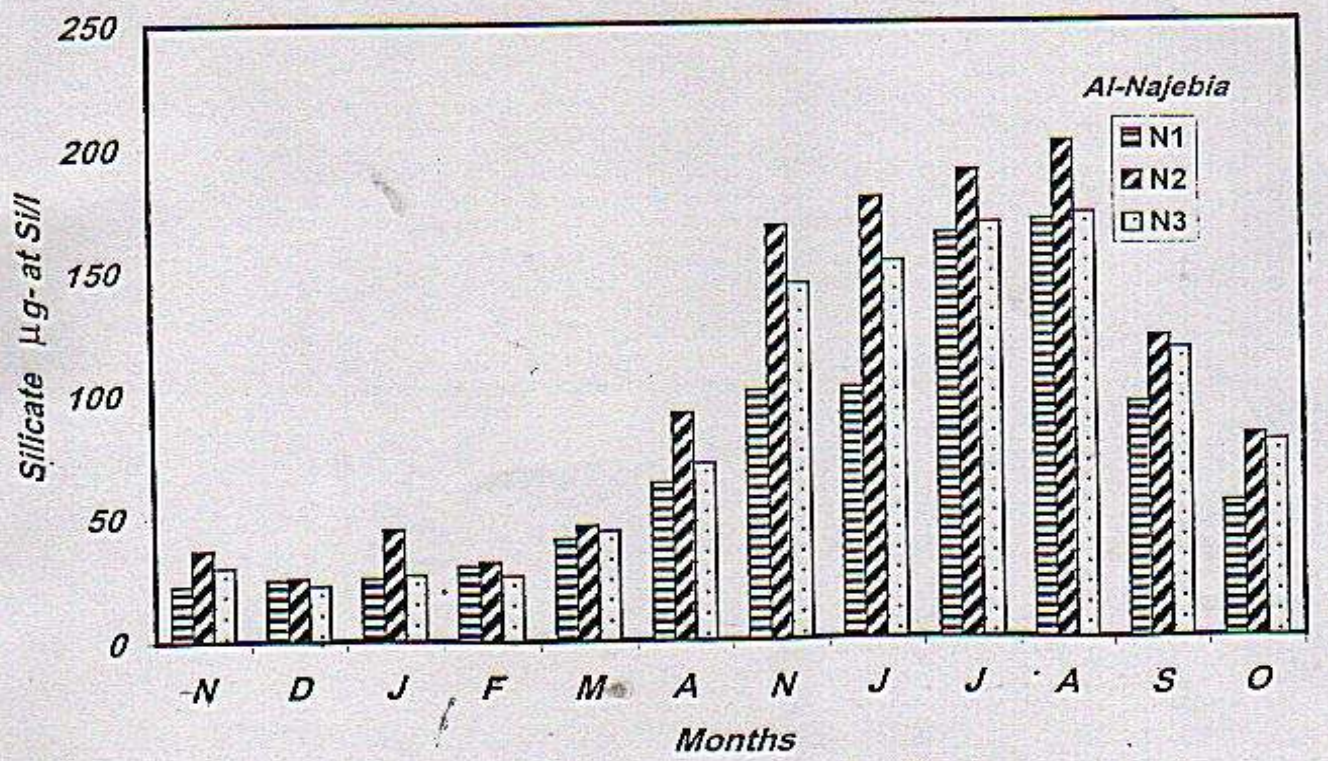

Thisure( 4 ) Monthly and localized variations in silicate concentration 


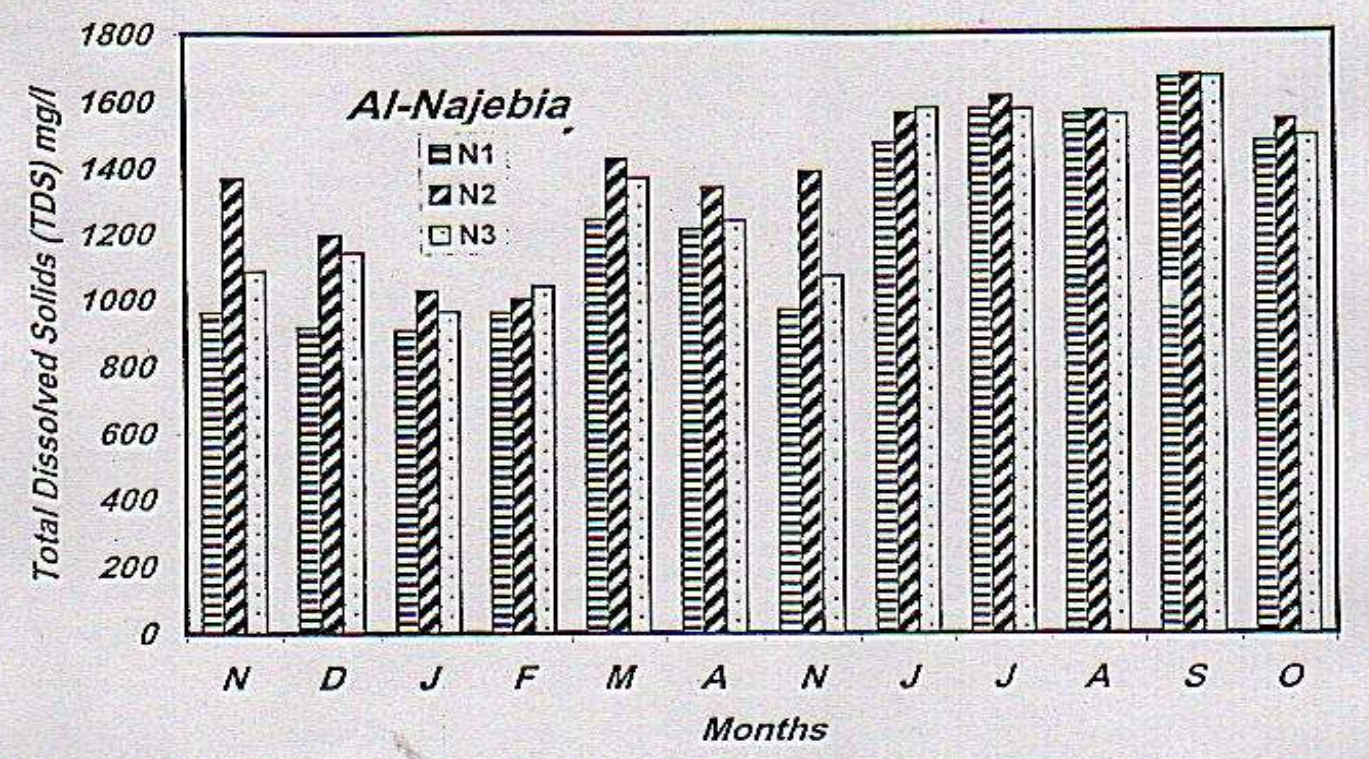

Fighre(5) Monthly and localized variations total suspended solitis concentration 


\section{References}

1- Al-Lami,A.A ; Al-Saadi, H. A; Kassim, T. I. and Al-Aubaidi, K. h. (1998). On the limnological features of Euphrates river, Iraq. J. Edu. Sci,29 : 38-50.

2- Al-Rubae, M. A. Jaafer (1997). Ecological study to Al-Udeem river and its impact on Tigris. MSc. Thesis; Baghdad University (hn Arabic)

3- Al-Saadi, H. A. , Al-Lami, A. A. and Kassim, T. A. (1996).Algal ecology and composition in the Qarmat Ali river. Iraq. River. $12: 27-38$.

4- Al- Nimma, B. A. B. (1982). A study on the limnology of the Tigris and Euphrates rivers , M. Sci. Thesis Salahddin Univ., Iraq.

5- $\quad$ APHA. Amererican Public Health Association (1985). Standard Methods for the examination of water and waste water $13^{\text {th }}$ ed. New-York.1193pp.

6- Benderschneider, K. and Robinson, R.J.(1952). A new spectrophotometric method for determination of nitrate in sea water, J. Mar. Res. 1: 69-87pp.

7- $\quad$ Fahad, K.K. (2002). An ecological study to the southern sector of Euphrates at Al-Nasriya city. MSc. Thesis; Basrah University. 57pp. (in Arabic).

8- Hammer, U.T. (1971). Limnological studies of the lakes and stream of the upper Quappelle river system, Saskatchewan, Canada. 1. Chemical and physical aspects of the lakes and draining system. Hydrobiol., 3-4:473-507pp.

9- Happy-Wood, C.M. and Priddle, J.(1984). The ecology of epipelic algae of five weish lake with special reference to volvocalean green flagellate. Chlorophyceae J.Phyco.20:109$124 \mathrm{pp}$.

10- Halton, H.; Kamp,L.; Nieslen, P. and Stuances,A.O.(1988). Phosphorous in soil, water and sediment. Hydrobiology. Vol.(20):9-34pp.

11- Hassan, F. M. (1997). A limnological study on Hilla river . Al-Mustainsiria J. Sci, 8 (1): $22-$ 30.

12- Hillbricht, A. and Simn, A.T.(1988). Spatial pattern of temperature, oxygen and nutrient concentration in two lake of different heated-water discharge. J.Poll. Abst. 20(60):165182pp.

13- Holton, H.; Kamp,L.; Nieslen, P. and Stuances,A.O.(1988). Phosphorous in soil, water and sediment. Hydrobiology. Vol.(20):9-34pp.

14- Hussein, S.A. (2001) Sources of organic pollution in Iraqi inland waters and possibilities of controlling and reuse. Marina Mesopotamia. 16(2): 489-505. (In Arabic)

15- Hussein, S. A. and K. K. Fahad. (2008) Seasonal variations in nutrients and chlorophyll concentrations in Al-Garaf canal one of the main branches to Euphrates $1^{\text {st }}$ Sci. Conf. Agric. Coll. 25-27 Nov., 2008(Basrah J. Agric. Sci. Special issue).

16- Hussein, S.A.; Al-Shawi, I.J.M. and Al-Nasir, A.M. (2001) Impact of Al-Najebia thermal energy power plant on aquatic ecosystem of Garmat Ali canal.I. Physico-chemical characteristics. Marina Mesopotamia , 16(2): 517-525.

17- Klarer, D.M. and Hickman, M. (1975). The effect of thermal effluent upon the standing crop of an epiphytic algal community Int. Revue. Hydrobiol. 60(1):17-62pp.

18- Lee, J. A. Choi, A. R. and Chung, I. K. (1995). Phytoplankton stoichiometry and nutrient status of the Sonaktong river. The Kor. J. Phycol., 10 (1) : 37-44.

19- Lind, O. T. (1979). Hand book of common methods in limnology. $2^{\text {nd }}$.Ed. London (109) pp

20- Mullin,J.B and Riley, J.P.(1955). The spectrophotometric determination of natural water with particular reference to sea water. Anal. Chim. Acta, 12:464-480pp.

21- Maulood, B. K.; Al-Azzawi, M. N. and Saadalla, H. A. (1994). An ecological study on the Tigris river pre and after crossing Baghdad. J. Coll. Educ. Univ. Baghdad 5 (1) : 43-50. 


\section{J.Thi-Qar Sci}

22- Murphy, J. and Riley, J.P.(1962). A modified single solution method for the determination of phosphate in natural water. Analyt. Chemistry Acta, 27:31-36.

23- Odum, E. P. (1971).Fundamentals of ecology . Philadelphia. P. 574

24- Parson, T.R.; Maita, Y. and Lalli, C.M.(1984). A manual of chemical and biological method for seawater analysis Peregaman Press Oxford: 60pp.

25- Payne, A.I. (1986). The ecology of tropical lake and river. New York. 26- Reid, G.K.(1961). Ecology of inland water and estuaries D. Van

Nostrand Co. New York 37.

27- Ruttner, F. (1963). fundrmentales of limnology. $3^{\text {ed }}$ Canda university of Toronto press . (307) pp.

28- Sharpley, A. (2001). Managing phosphorus agriculture and the environment. College of Science. The pennsylvania state University,

29- Shrimali, M. and Singh, K. P. (2001). New methods of nitrate removal from water, Environ, Pollut, 112 (3): 9-351.

تأثير محطة النجيبية للطاقة الحرارية على النظام البيئي المائي لقناة كرمة علي III. الاختلافات الثهرية في تراكيز العناصر المغذية والمواد الصلبة الذائبة الكلية صادق علي حسين و عماد جاسم الشاوي* و عبد العزيز محمود عبد الله قسم الأسماك والثروة البحرية، كلية الزراعة/ مركز علوم البحار * / جامعة البصرة

الخلاصة

درست الاختلافات الثهرية في المغذيات ( النتريت، النترات، والفوسفات والسليكا) فضلا عن قياس المواد الصلبة الذائبة الكلية في محطة النجيية لتوليد الطاقة الكهربائية. وانتخبت ثلاثة مواقع لجمع العينات اعتمادا علي نقاط سحب وتصريف ماء التبريد. واستمرت الدراسة للفترة الممتدة من تشرين الثاني 1997 إلى تشرين الأول 991 19 وكانت أدنى قيمة للنتريت (0 (، . مبكروغرام ذرة نيتروجين/ لتر) في تشرين الثاني وأعلاهـا ( VI، أ ميكروغرام ذرة نيتروجين/ لتر ) في كانون الثاني. وأظهرت النترات (NO3)

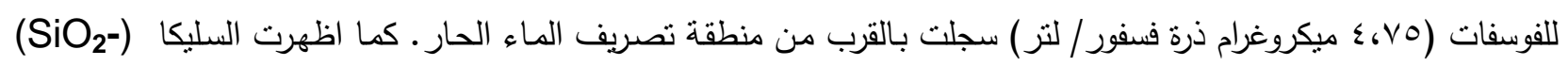
أعلى التراكيز في هذه المنطقة كذلك، وظهرت القيمة الأعلى ( ( ا ب ميكروغرام ذرة سليكا/ لتر) في آب. وسجلت المواد الصلبة الذائبة الكلية أعلى القيم (vo 1 ملغم/لتر) بالقرب من نقطة تصريف الماء الحار كذلك. ولم تسجل أية دراسة بيئية ، طويلة أو قصيرة الأمد, مماتلة على منطقة الدراسة أو أية بيئة أخرى في العراق. 